\title{
The microbiome profiling of fungivorous black tinder fungus beetle Bolitophagus reticulatus reveals the insight into bacterial communities associated with larvae and adults
}

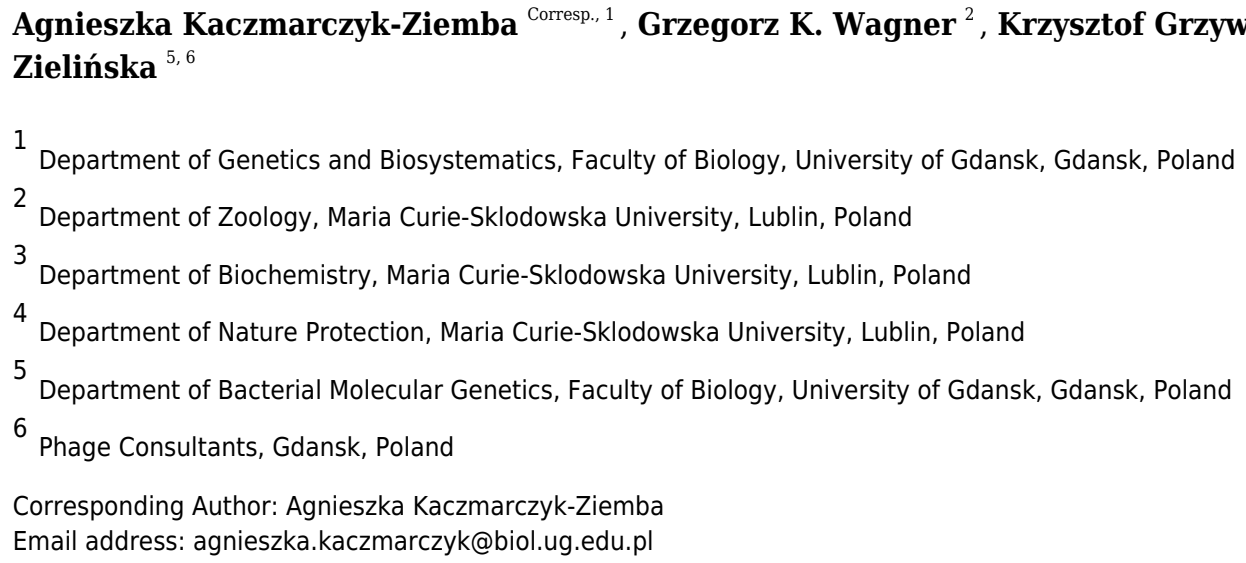

Saproxylic beetles play a crucial role in key processes occurring in forest ecosystems and together with fungi, contribute to the decomposition and mineralization of wood. Among this group are mycetophilic beetles which associate with wood-decaying fungi and use the fruiting body for nourishment and development. Therefore, their feeding strategy (especially in the case of fungivorous species) requires special digestive capabilities to take advantage of the nutritional value of fungal tissue. Although polypore-beetle associations have been investigated in numerous studies, detailed studies focusing on the microbiome associated with species feeding on fruiting bodies of polypores remain limited. Here we investigated the bacterial communities associated with larvae and adults of Bolitophagus reticulatus collected from Fomes fomentarius growing on two different host tree - beech (Fagus sp.) and birch (Betula sp.), respectively. Among 24 identified bacterial phyla, three were the most relatively abundant (Proteobacteria, Actinobacteria and Bacteroidetes). Moreover, we tried to find unique patterns of bacteria abundances which could be correlated with the long-term field observation showing that the fruiting bodies of $F$. fomentarius, growing on birch are more inhabited by beetles than fruiting bodies of the same fungus species growing on beech. Biochemical analyses showed that the level of protease inhibitors and secondary metabolites in $F$. fomentarius is higher in healthy fruiting bodies than in the inhabited ones. However, tested microbiome samples primarily clustered by developmental stage of $B$. reticulatus and host tree did not appear to impact the taxonomic distribution of the communities. This observation was supported by statistical analyses. 
1 The microbiome profiling of fungivorous black tinder fungus beetle Bolitophagus reticulatus

2 reveals the insight into bacterial communities associated with larvae and adults

3

4 Agnieszka Kaczmarczyk-Ziemba', Grzegorz K. Wagner ${ }^{2}$, Krzysztof Grzywnowicz ${ }^{3}$, Marek

5 Kucharczyk $^{4}$, Sylwia Zielińska ${ }^{5,6}$

$6{ }^{1}$ Department of Genetics and Biosystematics, Faculty of Biology, University of Gdansk, Wita

7 Stwosza 59, 80-308 Gdansk, Poland, agnieszka.kaczmarczyk@biol.ug.edu.pl

$8{ }^{2}$ Department of Zoology, Maria Curie-Sklodowska University, Akademicka 19, 20-033 Lublin,

9 Poland, grzegorz.wagner@umcs.lublin.pl

$10{ }^{3}$ Department of Biochemistry, Maria Curie-Sklodowska University, Akademicka 19, 20-033

11 Lublin, Poland, grzyw@poczta.umcs.lublin.pl

$12{ }^{4}$ Department of Nature Protection, Maria Curie-Sklodowska University, Akademicka 19, 20-033

13 Lublin, Poland, marek.kucharczyk@umcs.lublin.pl

$14{ }^{5}$ Department of Bacterial Molecular Genetics, Faculty of Biology, University of Gdansk, Wita

15 Stwosza 59, 80-308 Gdansk, Poland, sylwia.zielinska@biol.ug.edu.pl

$16{ }^{6}$ Phage Consultants, Partyzantow 10/18, 80-254 Gdansk, Poland

18 Corresponding Author:

19 Agnieszka Kaczmarczyk-Ziemba ${ }^{1}$

20 Wita Stwosza 59, 80-308 Gdansk, Poland

21 Email address: agnieszka.kaczmarczyk@biol.ug.edu.pl 


\section{Abstract}

24

25

26

27

Saproxylic beetles play a crucial role in key processes occurring in forest ecosystems and together with fungi, contribute to the decomposition and mineralization of wood. Among this group are mycetophilic beetles which associate with wood-decaying fungi and use the fruiting body for nourishment and development. Therefore, their feeding strategy (especially in the case of fungivorous species) requires special digestive capabilities to take advantage of the nutritional value of fungal tissue. Although polypore-beetle associations have been investigated in numerous studies, detailed studies focusing on the microbiome associated with species feeding on fruiting bodies of polypores remain limited. Here we investigated the bacterial communities associated with larvae and adults of Bolitophagus reticulatus collected from Fomes fomentarius growing on two different host tree - beech (Fagus sp.) and birch (Betula sp.), respectively. Among 24 identified bacterial phyla, three were the most relatively abundant (Proteobacteria, Actinobacteria and Bacteroidetes). Moreover, we tried to find unique patterns of bacteria abundances which could be correlated with the long-term field observation showing that the fruiting bodies of $F$. fomentarius, growing on birch are more inhabited by beetles than fruiting bodies of the same fungus species growing on beech. Biochemical analyses showed that the level of protease inhibitors and secondary metabolites in F. fomentarius is higher in healthy fruiting bodies than in the inhabited ones. However, tested microbiome samples primarily clustered by developmental stage of $B$. reticulatus and host tree did not appear to impact the taxonomic distribution of the communities. This observation was supported by statistical analyses. 


\section{Introduction}

Saproxylic beetles are directly or indirectly related to wood during at least one developmental stage (Speight, 1989). They play a critical role in key processes occurring in forest ecosystems and together with fungi, contribute to the decomposition and mineralization of wood (Gutowski \& Buchholz, 2000). These species are a major component of forest biodiversity and help to maintain a specific homeostasis of the ecosystem. Saproxylic beetles can occupy several ecological nishes and therefore xylophages, cambiophages, predators, necrophiles, and finally mycetophiles can be distinguished (Gutowski et al., 2004).

Mycetophilic beetles associate with wood-decaying fungi and use the fruiting body for nourishment and development (Gutowski, 2006). Their feeding strategy requires special digestive capabilities to take advantage of the nutritional value of fungal tissue. Associated microorganisms play a crucial role in those processes. Although polypore-beetle associations have been investigated in numerous studies (Nikitsky \& Schigel, 2004; Schigel, Niemelä \& Kinnunen, 2006; Schigel, 2009, 2011, 2012), the detailed projects focused on their microbiome remain limited. Previous study was focused rather on microbiota associated with fungivorous insects (not only beetles, but also ants and termites) which cultivate fungi for food to take advantage of the nutritional value of fungal tissue (Aylward et al., 2014). However, the pilot investigations of microbiome of beetles associated with wood-decaying fungi also have been initiated. Recently, Wiater et al. (2018) identified bacteria Paenibacillus sp. in the gut of fungivorous darkling beetle Diaperis boleti (Tenebrionidae) feeding on polypore fungus Laetiporus sulphureus. These bacteria effectively degrade fungal $\alpha-(1 \rightarrow 3)$-glucan present in cell wall of fungi. More complex studies focused on profiling the microbiome of fungivorous beetles have not been performed yet. 
67

species occurring widely throughout European forests (Fig. 1A). This beetle belongs to tribe Bolitophagini which represent feeding strategy of dwellers. Larvae of beetles described as dwellers are fungivorous. In turn, their adults spend most of their life cycle inside the fruiting body and leave the fungus usually for mating and dispersal only (Schigel, Niemelä \& Kinnunen, 2006). B. reticulatus lives in close association with the perennial basidiocarps of Fomes fomentarius (L.) Fr. (commonly known as the tinder fungus; Fig. 1B) at all developmental stages and seems to be monophagous on this fungus species (Midtgaard, Rukke \& Sverdrup-Thygeson, 1998 and references therein).

The long-term field observations have shown that B. reticulatus is more often found inside $F$. fomentarius fruiting bodies growing on birch (Betula sp.) compared with those growing on beech (Fagus sp.). Moreover, polypores growing on beech trees are much larger and less inhabited by insects than fruiting bodies growing on birch (Wagner, 2018). The growth of fungi is closely correlated with the amount of catechins utilized (Arunachalam et al., 2003). Catechins can be taken and metabolized mainly by wood degrading fungi (Rayner \& Boddy, 1988).

Derivatives of catechins are also present in fungi themselves (Zhou \& Liu, 2010). Schwarze, Engels \& Mattheck (2000) has shown that the mycelium growing on the tree accumulates the secondary metabolites of its host, especially in the parts covering the fruiting bodies. This process may be correlated with observed differences in colonization degrees. Fungal metabolites are of considerable interest and remarkable importance as new lead compounds for plant and animal or human protection. Importantly, fungal polyketides are one of the largest and most structurally diverse classes of naturally occurring compounds, ranging from simple aromatic metabolites to complex macrocyclic lactones. They are inhibitors of enzymes, including 
89 proteases (Shen et al., 2015). However, the state of knowledge about biological activity of

90 substances derived from $F$. fomentarius remain limited. Antimicrobial activity of extracts

91 derived from the tinder fungus has been described by Dresch et al. (2015), while Chen et al.

92 (2008) found that its exopolysaccharide (EPS) has direct antiproliferative effect in vivo. In turn,

93 some active compounds (e.g. catalase, extracellular laccase, manganese-dependent peroxidase,

94 carboxymethyl cellulose or xylanase) have been identified by Jaszek et al. (2006) and Elisashvili

95 et al. (2009). Nevertheless, there is still little known about the secondary metabolites and

96 inhibitors of proteases, especially with regard to fruiting bodies from the natural environment,

97 not from in vitro cultures. Therefore, more detailed and complex studies are needed to test the

98 hypothesis of the correlation between profiles of the secondary metabolites and inhibitors of

99 proteases, and the degree of polypores colonization.

100 In the present study, we investigated the bacterial communities associated with larvae and

101 adults of $B$. reticulatus collected from $F$. fomentarius growing on two different host tree - beech

102 and birch, respectively. We used the Next Generation Sequencing (NGS) of the 16S rRNA gene

103 to define whether the bacterial communities vary among the two tested developmental stages of

104 B. reticulatus. Lastly, we investigated the potential differences between microbiome profiles of

105 individuals collected from the tinder fungus growing on birch and beech and combined the

106 results with those obtained from studies on the biochemical composition of the $F$. fomentarius

107 fruiting bodies growing on wood of two different tree species.

108

109 Materials \& Methods

110 Study area and sample collection 
112 NP in south-eastern Poland. Field studies were approved by the Ministry of the Environment in

113 Poland (field study approval numbers: DLP-III-4102-21/1728/15/MD for the field study in

114 Poleski National Park and DPL-LLL-4102-609/1699/14/MD for the field study in Roztocze

115 National Park). Adults and larvae of black tinder fungus beetle B. reticulatus were caught in

116 fruiting bodies of $F$. fomentarius (Figs. 1A and 1B, respectively). Five adults and five larvae

117 were collected from the same fruit body growing on fallen birch trunk in Łowiszów (DMS:

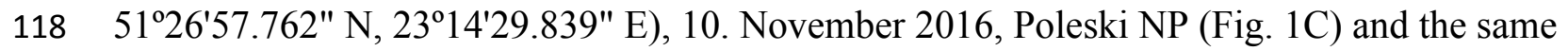

119 number of individuals were collected from one fungus growing on fallen beech stump in Obrocz

120 (DMS: 50³4'32.403" N, 23ํ24.388" E), 10. December 2016, Roztocze NP (Fig. 1D). Specimens

121 were separately placed into tubes and stored at $-30^{\circ} \mathrm{C}$. Afterwards the tubes with insects were

122 sent for further analyses to the Department of Genetics and Biosystematics, University of

123 Gdansk, Poland.

124 Studies on the occurrence of $F$. fomentarius fruiting bodies growing on birch and beech

125 were performed during the years 2013-2016. In those studies four fallen tree trunks from each

126 tree species were selected for further analyses. Chosen trunks were plentifully covered with

127 sporocarps. Beech trunks were located in Roztocze NP (localization - Obrocz, DMS:

$12850^{\circ} 34^{\prime} 32.403^{\prime \prime} \mathrm{N}, 2^{\circ} 0$ '24.388" E), while birch trunks were located in Poleski NP (localization:

129 Lipniak DMS: 51²7'51.363" N, 236'28.062" E). Healthy and settled fruiting bodies were

130 counted in the field and results are presented in Supplemental Table S1. For biochemical

131 analyses, fruiting bodies of the tinder fungus (Fig. 1B.) were collected in July 2016 from fallen

132 trunks of each tree species growing in two mentioned localities. In both sampling sites, 5

133 samples of healthy fruiting bodies and the same number of the inhabited fruiting bodies were 
134 taken. The fruiting bodies were inhabited by few species of mycophagous beetles with

135 dominance of the studied species - B. reticulatus. Samples were cut out from the tissue above the 136 hymenium.

137

138

DNA extraction

DNA was extracted from the whole bodies of $B$. reticulatus at two developmental stages

140 (larvae and adults, respectively). Insects were rinsed three times in sterile distilled water prior to

DNA extraction without soaking in ethanol. Specimens were homogenized with $0.7 \mathrm{~mm}$ garnet

beads in a high speed benchtop homogenizer FastPrep ${ }^{\circledR}-24$ (MP Biomedicals, USA) at $4.5 \mathrm{~m} / \mathrm{s}$

for $20 \mathrm{~s}$. The total DNA was then extracted using the Sherlock AX Purification Kit (A\&A

Biotechnology, Poland). Thus, presented study resolves the complex microbial population

structure of two developmental stages of $B$. reticulatus collected from fruiting bodies growing on different hosts. To avoid cross contamination of samples, the process was performed with sterile equipment. The quantity and quality of the extracted DNA were evaluated by using a Nano Drop

ND-1000 spectrophotometer (Nano Drop Technologies). After extraction, the DNA was stored at $-20^{\circ} \mathrm{C}$ until further use. Twelve samples consisting of genetic material isolated from larvae and adults (one individual per DNA isolate and three isolates per developmental stage collected from fungi growing on different hosts) were used for microbiome analyses.

$16 S$ rRNA gene sequencing and bacterial community analyses using the following primer set: 341F - 5'-CCTACGGGNGGCWGCAG-3' and 785R - 5'-

156 GACTACHVGGGTATCTAATCC-3'. The targeted gene region has been shown to be suitable 
157 for the Illumina sequencing (Klindworth et al., 2013). Libraries were prepared with a two-step

158 PCR protocol based on Illumina's "16S metagenomic library prep guide" (15044223 Rev. B)

159 with NEBNext ${ }^{\circledR}$ Q5 Hotstart High-Fidelity DNA polymerase (New England BioLabs Inc.)

160 according to the manufacturer's protocol, using Q5® Hot Start High-Fidelity 2X Master Mix

161 (NEBNext - New England BioLabs) and the Nextera Index kit (2x250bp). PCR was carried out

162 under the following conditions: $98^{\circ} \mathrm{C}$ for $30 \mathrm{sec}$ for initial denaturation of the DNA, followed by

16325 cycles of $98^{\circ} \mathrm{C}$ for $10 \mathrm{sec}, 55^{\circ} \mathrm{C}$ for $30 \mathrm{sec}, 72^{\circ} \mathrm{C}$ for $20 \mathrm{sec}$ and for additional 2 min at $72^{\circ} \mathrm{C}$

164 for final extension. Paired-end (PE, 2x250nt) sequencing with a 5\% PhiX spike-in was

165 performed with an Illumina MiSeq (MiSeq Reagent kit v2) at Genomed, Warsaw, Poland;

166 following the manufacturer's run protocols (Illumina, Inc., San Diego, CA, USA). Automatic

167 primary analysis and de-multiplexing of the raw reads were performed with MiSeq, with the use 168 of MiSeq Reporter (MSR) v2.6 (16S Metagenomics Protocol).

169 The genetic material isolated from 12 individuals was sequenced separately. Samples 170 were then marked as follows: L-Fagus-X and Im-Fagus-X for larva and adult collected from $F$.

171 fomentarius fruiting body growing on beech stump; L-Betula-X and Im-Betula-X for larva and

172 adult collected from $F$. fomentarius fruiting body growing on birch stump (X indicates the 173 number of individual).

174 The samples were processed and analyzed using the Quantitative Insights Into Microbial 175 Ecology (QIIME, version 1.9.1) pipeline (Caporaso et al., 2010). Paired-end reads from MiSeq 176 sequencing were quality trimmed and joined with PANDAseq version 2.8 (Masella et al., 2012) 177 with a quality threshold of 0.9 . The sequences that did not meet the quality criteria were removed 178 from further analysis (mean quality $>20$ ). Chimeric reads detection was performed with 179 VSEARCH, version 1.7.0 (Rognes et al., 2016), an open-source replacement of USEARCH 
180 software. Operational Taxonomic Unit (OTU) clustering was performed using UCLUST method, 181 version 1.2.22q (Edgar, 2010) and taxonomic assignment performed at 97\% against the SILVA 182 v.132 database (Quast et al., 2013). The Biological Observation Matrix (BIOM) table was used 183 as the core data for downstream analyses (McDonald et al., 2012). Any sequences that were 184 classified as Mitochondria or Chloroplast, as well as singletons were filtered out of the dataset. 185 Sample reads were rarefied to 38,188 reads. OTU saturation was evaluated with rarefaction 186 curves using Chao1 richness estimate. Moreover, the diversity indices were estimated, including 187 the Chao1, PD (a quantitative measure of phylogenetic diversity), Shannon, and Simpson indices and also the number of observed OTUs. Comparison of the microbial community structures was performed with the use of UniFrac (Lozupone \& Knight, 2005) and Emperor (Vázquez-Baeza et al., 2013). A two-sample $t$-test with a non-parametric Monte Carlo permutations $(\mathrm{n}=999)$ and Bonferroni correction was used to test for statistically significant difference in alpha diversity between predefined groups (according to (1) developmental stage, (2) host tree species, (3) both mentioned factors). A two-dimensional Principal Coordinate Analysis (PCoA) was conducted from weighted UniFrac distances obtained in previous steps. In order to determine if observed clusters of samples were significantly dissimilar, an analysis of similarity (ANOSIM; Clarke, 1993) was performed in QIIME with 999 permutations. dissimilarities in microbial community structures between particular samples and to access which family was responsible for the observed differences. Statistical analyses were performed using PAST 3.16 software (Ryan et al., 2001). Finally, to illustrate the most abundant bacterial families and community relationships across tested samples a heatmap and dendrogram was 202 generated with Bray-Curtis dissimilarity index. Bacterial families whose relative read abundance 
203 was less than $3 \%$ of at least one sample were removed. Those analyses were performed in $\mathrm{R}$

204 v.3.4.3 (Neuwirth, 2014; Ploner, 2015; Oksanen et al., 2018; Warnes et al., 2019).

205

206 Data availability

207 Bacterial 16 S reads for each sample were submitted to the European Nucleotide Archive 208 (ENA) database under accession number PRJEB23388.

209

Biochemical analyses

211

With the use of thin layer chromatography (TLC), comparison of entomotoxic and insecticidal features of fruiting bodies of $F$. fomentarius, enzyme analyses of the level of protease inhibitors (Sabotič, Ohm \& Künzler, 2016) and analyses of secondary metabolite profiles was performed (Anke \& Sterner, 2002). inhabited by beetles - separately) were mechanically ground and then homogenized in distilled water (for inhibitor determinations and TLC analyses of secondary metabolites) or in methanol (to TLC of secondary metabolites) in a Potter homogenizer; $100 \mathrm{mg}$ of shredded the sporocarp in $5 \mathrm{ml}$ of water or methanol. The homogenates were then centrifuged to give supernatants as assay preparations (Sobczyk, 2010; Jaruga, 2013). Protein in water extracts was determined by standard Bradford method (Bradford, 1976). marker proteases (used to determine type of inhibitor and specific $\mathrm{pH}$ ) according to Anson (1938). $0.1 \mathrm{ml}$ of the preparation was incubated with $0.1 \mathrm{ml}$ marker enzyme solution (pepsin at $\mathrm{pH} 5.0$ for aspartate acid protease inhibitors, trypsin and papain at $\mathrm{pH} 7.0$ for neutral serine and 
226 cysteine protease inhibitors and trypsin at $\mathrm{pH} 9.0$ for alkaline serine protease inhibitors) for 30

227 minutes at $37^{\circ} \mathrm{C}$. After this time, $0.5 \mathrm{ml}$ of the hemoglobin solution was added in buffer of

228 appropriate $\mathrm{pH}$ and incubated for 1 hour at $37^{\circ} \mathrm{C}$. The reaction was stopped by adding $2.0 \mathrm{ml}$ of

229 5\% TCA (trichloroacetic acid). Samples were centrifuged and their absorbance measured at 280

$230 \mathrm{~nm}$. As controls, water instead of preparation (sample for \% inhibition calculation) and marker

231 enzyme with water instead of specimen (zero-sample to reset the spectrophotometer) were used.

232 Percent inhibition was determined as the percentage of marker enzyme inhibition (Sobczyk, 233 2010).

234 During qualitative analysis of secondary metabolites by TLC, two types of extracts from

235 the fruiting bodies were analyzed: aqueous and methanol. TLC chromatography was developed

236 in two systems - ethanol : water (7:3) and ethyl acetate : acetic acid : water $(2: 1: 1)$. Merck ready

237 TLC plates (type: TLC Silica gel 60 F254) were used. Visualization of plates was done by UV

238 light observation (254 $\mathrm{nm}$ and $365 \mathrm{~nm}$ ), showing visible spots of secondary metabolites.

239 Qualitative analysis were made by spot diameter and intensity of glaring, relative rating

240 (standard TLC procedures). Then calculation of their retardation factor ( $\mathrm{Rf}-$ defined as the ratio

241 of the distance traveled by the center of a spot to the distance traveled by the solvent front) and

242 estimation of their relative UV intensity was performed (Jaruga, 2013). To determine the identity

243 of the compounds the $\mathrm{Rf}$ values were compared to the $\mathrm{Rf}$ value of compounds listed in databases

244 (Clevenger et al., 2017).

245

246 Results

247 General description of $16 S$ rRNA gene sequencing results

248 For each $B$. reticulatus sample, we obtained $>38,000$ good quality 16 S rRNA gene 249 sequences (V3-V4 region), ranging between 38, 188 for L-Betula-2 and 73,856 for Im-Betula-3. 
250 Rarefaction curves with Chaol diversity indices, indicating insect microbiome sampling depth

251 and saturation is shown in Fig. 2A. Observed curves almost reached a plateau at this sequencing

252 depth, suggesting that the sequencing was sufficient for microbiome characterization. More

253 details for sequence data for each sample, as well as the number of the observed OTUs and the

254 diversity indices are shown in Table 1. At least 319 OTUs, ranging from 319-1223, were

255 observed in different samples of $B$. reticulatus, which indicates that the microbial population is

256 complex.

257 In all samples, at least $98,94 \%$ of the reads could be classified to phylum level. Detailed

258 taxonomic analyses on different ranks are available in supplementary data as sunburst charts

259 (Supplemental Data S1) and also in a table (Supplemental Table S2).

260

261

Bacterial community composition

262

The analysis of bacterial community showed that for both larvae and adults of $B$.

reticulatus $>99.94 \%$ of total reads were represented by Bacteria (Supplemental Data S1 and

Supplemental Table S2). The remaining percentage comprised Archaea. The microbiomes tested in this study contained 24 phyla. The most abundant phyla across all tested stages were stages collected from $F$. fomentarius fruiting bodies growing on both tree species, those phyla jointly accounted for more than $81.45 \%$ of the total microbial sequences obtained. Other bacterial and archaeal phyla were present in tested microbial communities with different relative abundances given in Supplemental Table S2.

The most abundant classes among bacterial communities of all samples were 
273 of the total reads (Supplemental Data S1, Supplemental Table S2). The most abundant orders

274 among analyzed microbiome profiles were Corynebacteriales, Betaproteobacteriales and

275 Rhizobiales, accounting for more than $30 \%$ of the total reads. The most abundant family was

276 Burkholderiaceae and among that family the most abundant genus was Burkholderia-

277 Caballeronia-Parabirkholderia, which accounted for $16.17 \%$ of the reads on average (ranging

278 from $0.82 \%$ in L-Fagus-2 to $38.87 \%$ in Im-Fagus -1 ).

279 Similarities among the bacterial community structures associated with tested samples are

280 illustrated with a heatmap (Fig. 3). We identified 27 families, which relative abundance was not

281 less than $3 \%$ of at least one sample. Tested samples primarily clustered by developmental stage

282 of $B$. reticulatus and host tree did not appear to impact the taxonomic distribution of the

283 communities (Fig. 2B). This observation was supported by statistical analyses (ANOSIM: R =

$2840.88, p=0.002$, and the alpha diversity indices were only significantly different $(p=0.004)$

285 between samples grouped according to the developmental stage). In bacterial communities of

286 larvae Microbacteriaceae and Rhiziobiaceae were slightly more abundant, whereas

287 Acidobacteriaceae, Sphingomonadaceae, Rhodanobacteraceae, Mycobacteraceae and

288 Sphingomonadaceae were more abundant in microbiome of B. reticulatus adults. SIMPER

289 analysis showed that the last four families were primarily responsible for the differences between

290 microbial communities of larvae and adults.

291 Analyses of bacterial communities associated with B. reticulatus revealed the presence of

292 known endosymbionts. Wolbachia has been detected in 4 samples: all larvae collected from $F$.

293 fomentarius growing on beech $(0.08 \%$ for both L-Fagus- 1 and L-Fagus- 2 , and $0.14 \%$ for L-

294 Fagus-3) and in one adult related to birch $(<0.01 \%$ for Im-Betula-2). Moreover, two other known 
295 endosymbiotic bacteria have been detected - Arsenophonus (0.06\% for Im-Fagus-3 and L-

296 Betula-2) and Candidatus Cardinium (0.01\% for Im-Betula-1).

297

298 Level of protease inhibitors and secondary metabolite profiles in F. fomentarius fruiting bodies

299 The results of biochemical analyses of the collected fruiting bodies showed that the level

300 of inhibition was higher for aspartic acid protease inhibitors in fungus from beech, and for

301 cysteine inhibitors and serine neutral proteases in fungus from birch (Table 2). In the case of

302 inhibitors of basic serine proteases, the levels from both trees were similar (Table 2). The level of

303 inhibitors is higher for healthy fruiting bodies than for the inhabited ones.

Positive TLC results were obtained for both types of extraction (water and methanol)

305

306

307

308

309

310

311

312

313

314

315

316
(Table 3), but only in the ethanol-water system. In the ethyl acetate-acetic acid-water system, no separation was obtained and only a spot corresponding to the initial application on the TLC plate was apparent. The strongest spot of secondary metabolites, 0.11176 , from a healthy beech tree, has not been identified. There were no differences in the intensities of the weaker 0.9092 spot from the healthy beech tree across samples and the 0.8235 spot, which was present in all fruiting bodies. There is a visible decrease in the intensity of spots $0.7058,0.1176$ and 0.7882 on beech between healthy and colonized fruit bodies. Spots 0.11176 (methanol), 0.9092 (water) and 0.7882 (water) are absent in the fruiting bodies growing on the birch, both healthy and inhabited. The 0.7058 spot in all samples from the aqueous extract did not change its intensity, in comparison to spots with the same Rf from the methanol extract.

\section{Discussion}


Bacteroidetes phyla, as well as Alpha- and Gammaproteobacteria classes have been listed as the

Vesbach, 2012; Jones, Sanchez \& Fierer, 2013; Yun et al., 2014; Kim et al., 2017), and also in those cultivating fungi (Aylward et al., 2014). Moreover, identified patterns of the abundance

remained in congruence with the results of our previous study focused on microbial communities associated with Hoplothrips carpathicus (Thysanoptera), which also inhabits fruiting bodies of F. fomentarius (Kaczmarczyk et al., 2018). bacterial communities associated with fungivorous $H$. carpathicus this genus was also noted (Kaczmarczyk et al., 2018), but it was not as abundant as in B. reticulatus. Burkholderia was also identified in bacterial communities associated with other insects e.g. in the larvae of the wood-feeding beetle Prionoplus reticularis (Reid et al., 2011), in longicorn beetle Prionus insularis (Park et al., 2007) or in members of Heteroptera (Kikuchi, Hosokawa \& Fukatsu, 2010). This genus is linked with several functions - nitrogen fixation (Estrada-De et al., 2001), defence mechanisms (Santos et al., 2004), aromatic compound degradation (Laurie \& LloydJones, 1999; Bugg et al., 2011), and detoxification of tree defence compounds (Smith et al., 2007; Adams et al., 2013). Furthermore, a symbiotic relationship between Burkholderia and white rot fungus Phanerochaete chrysosporium was described by Seigle-Murandi et al. (1996).

339 This fungus species, similar to $F$. fomentarius, degrades lignocellulosic materials. Nevertheless, 
340 symbiotic relationships between $F$. fomentarius and microorganisms has not been investigated

341 yet. Therefore, one may not exclude that Burkholderia identified in bacterial communities of $B$.

342 reticulatus is connected also with the tinder fungus via a symbiotic relationship. However, its

343 presence in microbiome profiles of different developmental stages of black tinder fungus beetle

344 is thought to be related to the potential of Burkholderia representatives to degradation of

345 aromatic compounds (e.g. lignin) present in B. reticulatus food source.

346 Besides Burkholderia, we found in tested bacterial communities also other genera, which

347 have been considered as degraders of aromatic compounds. Pseudomonas (Pseudomonadaceae)

348 and Serratia (Enterobacteriaceae) identified previously in microbiome of the mountain pine

349 beetle Dendroctonus ponderosae, have been described as terpene degraders (Adams et al., 2013).

350 In turn, Sphingomonas, Sphingobium, Novosphingobium and Sphingopyxis

351 (Sphingomonadaceae) have been recognised being involved in degradation of various

352 recalcitrant aromatic compounds and polysaccharides (Aylward et al., 2013). Moreover,

353 Sphingomonas has been identified in microbiome of wood-boring beetle, Anoplophora

354 glabripennis as genus involved in the degradation of lignocellulose, hemicellulose, and other

355 aromatic hydrocarbons (Geib et al., 2009a; Geib et al., 2009b; Scully et al., 2013). Bosea

356 (Beijerinckiaceae; also found in present study) was in turn identified being associated with

357 cuticles of plant-ant genera Allomerus and Tetraponera (Seipke et al., 2013) and described as

358 hydrocarbon degrader (Yang et al., 2016). Comprehensive analyses of the functional microbiome

359 of arthropods (e.g. honeybees, fruit flies, cockroaches, termites, ants and beetles) show that

360 Burkholderia, Sphingomonas and Bosea are together involved in the same processes e.g. aerobic

361 metabolism, reacting with cytochrome $c$ or bypassing cytochrome $c$ (Esposti \& Romero, 2017). 

promotion of efficient digestion for extraction of maximum energy from ingested substrates.

364 Nevertheless, specific conditions in microenvironment of $F$. fomentarius fruiting body may 365 cause strong selective pressure against microorganisms that are not able to survive exposure to 366 defensive compounds produced by the tinder fungus. Recent study shed light on antimicrobial 367 activities of $F$. fomentarius. Kolundžíc et al. (2016) found that the tinder fungus extracts of 368 different polarity exhibit significant antimicrobial activity against nine bacterial strains 369 (including Staphylococcus aureus, Staphylococcus epidemidis, Bacillus subtilis or Klebsiella 370 pneumonia). In fact, the relative abundance of those bacteria in microbiome of $B$. reticulatus

371 were low and in most samples tested did not exceed 1\%. The observed antimicrobial activity of

$372 F$. fomentarius may be linked e.g. with polyphenols and $\beta$-glucans which abundances are 373 relatively high in its fruiting bodies (Seniuk et al., 2011; Zhao et al., 2013; Alves et al., 2013;

374 Zhu et al., 2015) or with sesquiterpens which have been described as active compounds 375 (identified enzyme inhibitors with antifungal, antibacterial and cytotoxic activities) (Abraham, 376 2001; Keller, 2018). These compounds may be considered as toxins for bacteria associated with 377 fungivorous species inhabiting $F$. fomentarius fruiting bodies. Thus, associated bacterial communities need to overcome the presence of such substances through resistance or tolerance mechanisms. S1) showed that in all tested bacterial communities genes involved in membrane transport and in metabolism of terpenoids and polyketides, as well as in xenobiotic biodegradation and metabolism should be elevated. Interestingly, terpenoids are main secondary metabolites of $F$. 
385 with $F$. fomentarius feeding species remain exposed to these compounds. Moreover, the similar

386 pattern of relative abundances were identified for predicted genes in the case of bacterial

387 communities associated with thrips $H$. carpathicus (Kaczmarczyk et al., 2018). This might mean

388 that similarities in predicted patterns of relative abundances of genes are characteristic for

389 bacterial communities associated with fungivorous species inhabiting fruiting bodies of wood-

390 decaying fungi. However, the in silico predicted functions need to be validated in vitro in future 391 studies.

392 The additional aim of the present study was connected with the long-term field

393 observations showing that there is a difference between the amount of healthy and colonized

394 sporocarps growing on the trunks of both beech and birch (Supplemental Table S1). In the case

395 of beech, the $F$. fomentarius fruiting bodies inhabited by insects were collected less frequently

396 ( $\sim 27 \%$ on average, in the range from $19 \%$ to $33 \%$ of all collected fruiting bodies growing on

397 selected trunks). In turn, the number of colonized sporocarps growing on birch was higher

398 ( $\sim 66 \%$ on average) and ranged from $46 \%$ to $85 \%$ of all collected fruiting bodies growing on

399 these trees. To identify the potential factors related to the observed differences in degree of

400 fruiting bodies colonization by insects, we identified trends in biochemical profiles of fruiting

401 bodies growing on two different tree hosts.

402 We analyzed the level of protease inhibitors and secondary metabolites detected in $F$.

403 fomentarius fruiting bodies, which are involved in protection against fungivorous insects (Anke

404 \& Sterner, 2002; Sabotič, Ohm \& Künzler, 2016). Moreover, we investigated the bacterial

405 communities of larvae and adults of B. reticulatus for potential differences which could be

406 related to host-tree species. 
The biochemical analysis showed that a higher level of protease inhibitors was observed 408 in healthy fruiting bodies than in colonized ones. Unfortunately, no previous research has been

409

410

411

412

413

414

415

416

417

418

419

420

421

422

423

424

425

426

427

428

done to investigate this phenomenon, so it is unclear why inhibitor levels are lower in colonized

fruiting bodies. Changes in levels of acidic, neutral, and alkaline proteases in colonized

sporocarps may resulted from the inherent properties of insect proteases, which are dominated by

serine and cysteine proteases over aspartic proteases (Terra \& Ferreira, 1994). In turn, a high

level of acid inhibitors of aspartic proteases may be additionally associated with the protection of

fruiting bodies against pathogenic and saprophytic microscopic fungi (mainly molds) (Monod et

al., 2002), which have high levels of aspartic proteases in their proteolytic apparatus.

Moreover, performed analyses indicated the presence of unidentified secondary

metabolites in samples of non-colonized fruiting bodies collected from beech. Probably, these

substances are able to determine the susceptibility of fruiting bodies to be colonized by insects

and, generally, to be infected. It is worth noting that even dozen-year-old specimens of $F$.

fomentarius, growing on beech wood, are usually completely healthy, while fungi growing on

the birch, are colonized by insects and has signs of the presence of pathogenic fungi (e.g. mold).

Therefore, some obvious contributing factors to this phenomenon (e.g. size of fruiting body, sun

exposure or age) seem to be insignificant for determining the degree of fruiting bodies

colonization by insects. Some authors showed that Fagus sylvatica produces flavonoids and

organic acids which can be classified as repellents against insects (Harborne, 1997; Simmonds, 2003; Treutter, 2005; Podgórski \& Podgórska, 2009). The accumulation of some flavonoids in the fruiting bodies of $F$. fomentarius could be a barrier against the fungivorous beetles. At this stage, it cannot be excluded that flavonoids are among those unidentified secondary metabolites 
429 detected in present study. However, the identification of the secondary metabolites and their

430 potential impact on the relationship among host tree, fungi and insects require in-depth studies.

The biochemical analyses presented here should be treated with caution since the fruiting

432 bodies sampled for these analyses were collected earlier than those from which B. reticulatus

433

434

435

436

437

438

439

440

441

442

443

444

445

446

447

448

449

450

451 specimens were collected. Both sets of samples were collected for different studies. Although the obtained patterns needs to be tested in more complex studies where beetles would be collected from sporocarps, which would then be used for further biochemical analyses, the results presented here could be considered as insight in potential trends. More advanced biochemical analyses (e.g. using liquid chromatography or mass spectrometry) may provide a more complete insight into the biochemical profile of fruiting bodies. However, despite the observed trends in biochemical profiles, tested microbiome samples primarily clustered by developmental stage of B. reticulatus and host tree did not appear to impact the taxonomic distribution of the communities, what was supported by statistical analyses.

Additionally, known endosymbionts have been identified in microbiome profiles of $B$. reticulatus. Among them Wolbachia should receive a special attention. It is a well-known endosymbiont, which is estimated to be present in more than $65 \%$ of all insect species (Hilgenboecker et al., 2008; Lewis \& Lizé, 2015). Wolbachia is related to five commonly recognized manipulation schemes: feminization, parthenogenesis induction, early and late male killing, and cytoplasmic incompatibility (Engelstädter \& Hurst, 2009). It appears that these phenomena do not occur in B. reticulatus, but more comprehensive studies should be performed to test this hypothesis.

\section{Conclusions}


453 two developmental stages of $B$. reticulatus beetle with the use of $16 \mathrm{~S}$ rRNA sequence data. The 454 approach based on NGS technique allowed us to characterize of tested microbiome. Moreover, it 455 is the first approach to identification of factors which can be related to differences in degree of 456 fruiting bodies colonization by insects. Results of this study show biochemical differences in 457 fruiting bodies collected from birch and beech. We compared these results with those obtained 458 during analyses of bacterial communities associated with B. reticulatus. However, the host-tree 459 appears to have no effect on the bacterial communities associated with tested developmental 460 stages of $B$. reticulatus. Despite the observed trends in biochemical profiles of sporocarps 461 collected from both tree species, tested samples primarily clustered by developmental stage of $B$. 462 reticulatus. Moreover, endosymbiotic Alphaproteobacteria Wolbachia was identified for the first 463 time in B. reticulatus. 
465

466

467

468

469

470

471

472

473

474

475

476

477

478

479

480

481

482

483

484

485

486

487

\section{References}

Abraham W-R. 2001. Bioactive Sesquiterpenes Produced by Fungi are they Useful for Humans as Well. Current Medicinal Chemistry 8:583-606.

Adams AS., Aylward FO., Adams SM., Erbilgin N., Aukema BH., Currie CR., Suen G., Raffa KF. 2013. Mountain Pine Beetles Colonizing Historical and Naïve Host Trees Are Associated with a Bacterial Community Highly Enriched in Genes Contributing to Terpene Metabolism. Applied and Environmental Microbiology 79:3468-3475. DOI: 10.1128/AEM.00068-13.

Alves MJ., Ferreira ICFR., Froufe HJC., Abreu RMV., Martins A., Pintado M. 2013. Antimicrobial activity of phenolic compounds identified in wild mushrooms, SAR analysis and docking studies. Journal of Applied Microbiology 115:346-357. DOI:

10.1111/jam.12196.

Anke H., Sterner O. 2002. Insecticidal and nematicidal metabolites from fungi. In: The Mycota Industrial Applications. Berlin: Springer Verlag, 109-135.

Anson ML. 1938. the Estimation of Pepsin, Trypsin, Papain, and Cathepsin With Hemoglobin. The Journal of General Physiology 22:79-89. DOI: 10.1085/jgp.22.1.79.

Arunachalam M., Mohan Raj M., Mohan N., Mahadevan A. 2003. Biodegradation of Catechin. Proceedings of the Indian National Science Academy B69:353-370. DOI: 10.1017/S000711451000396X.

Aylward FO., McDonald BR., Adams SM., Valenzuela A., Schmidt RA., Goodwin LA., Woyke T., Currie CR., Suen G., Poulsen M. 2013. Comparison of 26 Sphingomonad Genomes Reveals Diverse Environmental Adaptations and Biodegradative Capabilities. Applied and Environmental Microbiology 79:3724-3733. DOI: 10.1128/AEM.00518-13. 
488 Aylward FO., Suen G., Biedermann PHW., Adams AS., Scott JJ., Malfatti SA., Glavina del Rio

489 T., Tringe SG., Poulsen M., Raffa KF., Klepzig KD., Currie CR. 2014. Convergent bacterial

490 microbiotas in the fungal agricultural systems of insects. mBio 5:e02077. DOI:

$491 \quad$ 10.1128/mBio.02077-14.

492 Bradford MM. 1976. A rapid and sensitive method for the quantitation of microgram quantities 493 of protein utilizing the principle of protein-dye binding. Analytical Biochemistry 72:248494254.

495

496

497

498

499

500

501

502

503

504

505

506

507

508

509

510

Bugg TD., Ahmad M., Hardiman EM., Singh R. 2011. The emerging role for bacteria in lignin degradation and bio-product formation. Current Opinion in Biotechnology 22:394-400. DOI: 10.1016/j.copbio.2010.10.009.

Caporaso JG., Kuczynski J., Stombaugh J., Bittinger K., Bushman FD., Costello EK., Fierer N., Gonzalez Pena A., Goodrich JK., Gordon JI., Huttley GA., Kelley ST., Knights D., Koenig JE., Ley RE., Lozupone CA., McDonald D., Muegge BD., Pirrung M., Reeder J., Sevinsly JR., Turnbaugh PJ., Walters WA., Widmann J., Yatsunenko T., Zaneveld J., Knight R. 2010. QIIME allows analysis of high-throughput community sequencing data. Nature Methods 7:335-336.

Chen W., Zhao Z., Chen S-F., Li Y-Q. 2008. Optimization for the production of exopolysaccharide from Fomes fomentarius in submerged culture and its antitumor effect in vitro. Bioresource Technology 99:3187-3194. DOI: 10.1016/J.BIORTECH.2007.05.049.

Clarke KR. 1993. Non-parametric multivariate analyses of changes in community structure. Australian Journal of Ecology 18:117-143. DOI: 10.1111/j.1442-9993.1993.tb00438.x.

Clevenger KD., Bok JW., Ye R., Miley GP., Verdan MH., Velk T., Chen C., Yang K., Robey MT., Gao P., Lamprecht M., Thomas PM., Islam MN., Palmer JM., Wu CC., Keller NP., 
511 Kelleher NL. 2017. A scalable platform to identify fungal secondary metabolites and their 512 gene clusters. Nature Chemical Biology 13:895-901. DOI: 10.1038/nchembio.2408.

513 Colman DR., Toolson EC., Takacs-Vesbach CD. 2012. Do diet and taxonomy influence insect

514 gut bacterial communities? Molecular Ecology 21:5124-5137. DOI: 10.1111/j.1365-

$515 \quad$ 294X.2012.05752.x.

516 Dresch P., D’Aguanno MN., Rosam K., Grienke U., Rollinger JM., Peintner U. 2015. Fungal 517 strain matters: colony growth and bioactivity of the European medicinal polypores Fomes 518 fomentarius, Fomitopsis pinicola and Piptoporus betulinus. AMB Express 5:4. DOI: $519 \quad 10.1186 / \mathrm{s} 13568-014-0093-0$.

520 Edgar RC. 2010. Search and clustering orders of magnitude faster than BLAST. Bioinformatics 521 26:2460-2461. DOI: 10.1093/bioinformatics/btq461.

522 Elisashvili V., Kachlishvili E., Tsiklauri N., Metreveli E., Khardziani T., Agathos SN. 2009.

523 Lignocellulose-degrading enzyme production by white-rot Basidiomycetes isolated from the 524 forests of Georgia. World Journal of Microbiology and Biotechnology 25:331-339. DOI: 10.1007/s11274-008-9897-X.

526

527

528

529

530

531

532

533

Engelstädter J., Hurst GDD. 2009. The Ecology and Evolution of Microbes that Manipulate Host Reproduction. Annual Review of Ecology, Evolution, and Systematics 40:127-49. DOI: 10.1146/annurev.ecolsys.110308.120206.

Esposti MD., Romero EM. 2017. The functional microbiome of arthropods. PLoS One 12:e0176573. DOI: 10.1371/journal.pone.0176573.

Estrada-De P., Santos L., Bustillos-Cristales RO., Caballero-Mellado JS. 2001. Burkholderia, a Genus Rich in Plant-Associated Nitrogen Fixers with Wide Environmental and Geographic Distribution. Applied and Environmental Microbiology 67:2790-2798. DOI: 
535 Geib SM., Jimenez-Gasco MDM., Carlson JE., Tien M., Hoover K. 2009a. Effect of host tree

536 species on cellulase activity and bacterial community composition in the gut of larval Asian

537 longhorned beetle. Environmental Entomology 38:686-699.

538 Geib SM., Del Mar Jimenez-Gasco M., Carlson JE., Tien M., Jabbour R., Hoover K. $2009 b$.

539 Microbial Community Profiling to Investigate Transmission of Bacteria Between Life

540 Stages of the Wood-Boring Beetle, Anoplophora glabripennis. Microbial Ecology 58:199-

541 211. DOI: $10.1007 / \mathrm{s} 00248-009-9501-4$.

542 Grienke U., Zöll M., Peintner U., Rollinger JM. 2014. European medicinal polypores - A

543 modern view on traditional uses. Journal of Ethnopharmacology 154:564-583. DOI:

$544 \quad$ 10.1016/j.jep.2014.04.030.

545 Gutowski JM. 2006. Saproksyliczne chrząszcze. Kosmos 55:53-73.

546 Gutowski JM., Bobiec A., Pawlaczyk P., Zub K. 2004. Drugie życie drzewa. Warszawa-

547 Hajnówka: WWF Polska.

548 Gutowski JM., Buchholz L. 2000. Owady leśne - zagrożenia i propozycje ochrony. Wiadomości $549 \quad$ Entomologiczne 18:43-72.

550 Harborne JB. 1997. Ekologia biochemiczna. Warsaw: Wydawnictwo Naukowe PWN.

551 Hilgenboecker K., Hammerstein P., Schlattmann P., Telschow A., Werren JH. 2008. How many

552 species are infected with Wolbachia? A statistical analysis of current data. FEMS

$553 \quad$ Microbiology Letters 281:215-20. DOI: 10.1111/j.1574-6968.2008.01110.x.

554 Jaruga A. 2013. Inhibitory metabolizmu alkoholu z grzybów wyższych. Master's Thesis. Maria

$555 \quad$ Curie-Skłodowska Univeristy.

556 Jaszek M., Żuchowski J., Dajczak E., Cimek K., Graz M., Grzywnowicz K. 2006. Ligninolytic 
557

558

559

560

561

562

563

564

565

566

567

568

569

570

571

572

573

574

575

576

577

578

579

enzymes can participate in a multiple response system to oxidative stress in white-rot basidiomycetes: Fomes fomentarius and Tyromyces pubescens. International Biodeterioration \& Biodegradation 58:168-175. DOI: 10.1016/J.IBIOD.2006.06.012.

Jones RT., Sanchez LG., Fierer N. 2013. A cross-taxon analysis of insect-associated bacterial diversity. PLoS One 8:e61218. DOI: 10.1371/journal.pone.0061218.

Kaczmarczyk A., Kucharczyk H., Kucharczyk M., Kapusta P., Sell J., Zielińska S. 2018. First insight into microbiome profile of fungivorous thrips Hoplothrips carpathicus (Insecta: Thysanoptera) at different developmental stages: molecular evidence of Wolbachia endosymbiosis. Scientific Reports 8:14376. DOI: 10.1038/s41598-018-32747-x.

Keller NP. 2018. Fungal secondary metabolism: regulation, function and drug discovery. Nature Reviews Microbiology:1. DOI: 10.1038/s41579-018-0121-1.

Kikuchi Y., Hosokawa T., Fukatsu T. 2010. An ancient but promiscuous host-symbiont association between Burkholderia gut symbionts and their heteropteran hosts. The ISME Journal 5:446-460. DOI: 10.1038/ismej.2010.150.

Kim JM., Choi M-Y., Kim J-W., Lee SA., Ahn J-H., Song J., Kim S-H., Weon H-Y. 2017. Effects of diet type, developmental stage, and gut compartment in the gut bacterial communities of two Cerambycidae species (Coleoptera). Journal of Microbiology 55:2130. DOI: $10.1007 / \mathrm{s} 12275-017-6561-\mathrm{x}$.

Klindworth A., Pruesse E., Schweer T., Peplies J., Quast C., Horn M., Glöckner FO. 2013. Evaluation of general 16S ribosomal RNA gene PCR primers for classical and nextgeneration sequencing-based diversity studies. Nucleic Acids Research 41:1-11. DOI: $10.1093 / \mathrm{nar} / \mathrm{gks} 808$.

Kolundžíć M., Grozdaníć ND., Dodevska M., Milenkovíć M., Sisto F., Miani A., Farronato G., 
580

581

582

583

584

585

586

587

588

589

590

591

592

593

594

595

596

597

598

599

600

601

602

Kundakovíć T. 2016. Antibacterial and cytotoxic activities of wild mushroom Fomes

fomentarius (L.) Fr., Polyporaceae. Industrial Crops \& Products 79:110-115. DOI:

10.1016/j.indcrop.2015.10.030.

Langille MGI., Zaneveld J., Caporaso JG., Mcdonald D., Knights D., Reyes JA., Clemente JC., Burkepile DE., Vega Thurber RL., Knight R., Beiko RG., Huttenhower C. 2013. Predictive functional profiling of microbial communities using 16S rRNA marker gene sequences HHS Public Access. Nature Biotechnology 31:814-821. DOI: 10.1038/nbt.2676.

Laurie AD., Lloyd-Jones G. 1999. The phn Genes of Burkholderia sp. Strain RP007 Constitute a Divergent Gene Cluster for Polycyclic Aromatic Hydrocarbon Catabolism. Journal of Bacteriology 181:531-540.

Lewis Z., Lizé A. 2015. Insect behaviour and the microbiome. Current Opinion in Insect Science 9:86-90. DOI: 10.1016/J.COIS.2015.03.003.

Lozupone C., Knight R. 2005. UniFrac: a new phylogenetic method for comparing microbial communities. Applied and Environmental Microbiology 71:8228-8235.

Masella AP., Bartram AK., Truszkowski JM., Brown DG., Naufeld JD. 2012. PANDAseq: paired-end assembler for illumina sequences. BMC Bioinformatics 13:31. DOI: 10.1186/1471-2105-13-31.

McDonald D., Clemente JC., Kuczynski J., Rideout JR., Stombaugh J., Wendel D., Wilke A., Huse S., Hufnagle J., Meyer F., Knight R., Caporaso JG. 2012. The Biological Observation Matrix (BIOM) format or: how I learned to stop worrying and love the ome-ome.

GigaScience 1:1-6. DOI: 10.1186/2047-217X-1-7.

Midtgaard F., Rukke BA., Sverdrup-Thygeson A. 1998. Habitat use of the fungivorous beetle Bolitophagus reticulatus (Coleoptera: Tenebrionidae): Effects of basidiocarp size, humidity 

and competitors. European Journal of Entomology 95:559-570.

604 Monod M., Capoccia S., Léchenne B., Zaugg C., Holdom M., Jousson O. 2002. Secreted 605 proteases from pathogenic fungi. International Journal of Medical Microbiology 292:405$606 \quad 419$.

607 Neuwirth E. 2014. RColorBrewer: ColorBrewer Palettes. R package version 1.1-2.

608 https://CRAN.R-project.org/package=RColorBrewer.

609 Nikitsky NB., Schigel DS. 2004. Beetles in polypores of the Moscow region: checklist and $610 \quad$ ecological notes. Entomologica Fennica 15:6-22.

611 Oksanen J., Blanchet, F. Guillaume Friendly M., Kindt R., Legendre P., McGlinn D., Minchin

612 PR., O’Hara RB., Simpson GL., Solymos P., Henry M., Stevens H., Szoecs E., Wagner H. 613 2018. vegan: Community Ecology Package. R package version 2.5-3. https:/CRAN.R614 project.org/package= $=$ vegan.

615 Park D-S., Oh H-W., Heo S-Y., Jeong W-J., Shin DH., Bae KS., Park H-Y. 2007.

616 Characterization of an extracellular lipase in Burkholderia sp. HY-10 isolated from a 617 longicorn beetle. Journal of Microbiology 45:409-417.

618 Ploner A. 2015. Heatplus: Heatmaps with row and/or column covariates and colored clusters. R 619 package version 2.24.0. https://github.com/alexploner/Heatplus.

620 Podgórski A., Podgórska B. 2009. Drzewa w pomniki zaklęte. Drzewa pomnikowe w Rudzie 621 Śląskiej. Katowice: KOS.

622 Quast C., Pruesse E., Yilmaz P., Gerken J., Schweer T., Yarza P., Peplies J., Glöckner FO. 2013. 623 The SILVA ribosomal RNA gene database project: improved data processing and web624 based tools. Nucleic Accids Research 41:D590-D596. DOI: 10.1093/nar/gks1219. 625 Rayner ADM., Boddy L. 1988. Fungal decomposition of wood. Its biology and ecology. John 
626 Wiley \& Sons Ltd.

627 Reid NM., Addison SL., Macdonald LJ., Lloyd-Jones G. 2011. Biodiversity of active and

628 inactive bacteria in the gut flora of wood-feeding huhu beetle larvae (Prionoplus

629 reticularis). Applied and Environmental Microbiology 77:7000-6. DOI:

$630 \quad$ 10.1128/AEM.05609-11.

631 Rognes T., Flouri T., Nichols B., Quince C., Mahé F. 2016. VSEARCH: a versatile open source 632 tool for metagenomics. PeerJ 4:e2584. DOI: 10.7717/peerj.2584.

633 Ryan PD., Hammer Ø., Harper DA., Paul Ryan DD. 2001. PAST: Paleontological statistics

634 software package for education and data analysis. Palaeontologia Electronica 178kb. T.

635 Harper. Geological Museum 4:5-7.

636 Sabotič J., Ohm RA., Künzler M. 2016. Entomotoxic and nematotoxic lectins and protease 637 inhibitors from fungal fruiting bodies. Applied Microbiology and Biotechnology 100:91$638 \quad 111$.

639 Santos A V., Dillon RJ., Dillon VM., Reynolds SE., Samuels RI. 2004. Ocurrence of the 640 antibiotic producing bacterium Burkholderia sp. in colonies of the leaf-cutting ant Atta 641 sexdens rubropilosa. FEMS Microbiology Letters 239:319-323. DOI:

642 10.1016/j.femsle.2004.09.005.

643 Schigel DS. 2009. Polypore assemblages in boreal old-growth forests, and associated Coleoptera. $644 \quad$ University of Helsinki.

645 Schigel DS. 2011. Polypore - beetle associations in Finland. Annales Zoologici Fennici 48:319646 348. DOI: $10.5735 / 086.048 .0601$.

647 Schigel DS. 2012. Fungivory and host associations of Coleoptera: a bibliography and review of $648 \quad$ research approaches. Mycology 3:258-272. 
649 Schigel DS., Niemelä T., Kinnunen J. 2006. Polypores of western Finnish Lapland and seasonal 650 dynamics of polypore beetles. Karstenia 46:37-64.

651 Schwarze FWMR., Engels J., Mattheck C. 2000. Fungal Strategies of Wood Decay in Trees. $652 \quad$ Springer.

653 Scully ED., Geib SM., Hoover K., Tien M., Tringe SG., Barry KW., Glavina del Rio T., 654 Chovatia M., Herr JR., Carlson JE. 2013. Metagenomic Profiling Reveals Lignocellulose 655 Degrading System in a Microbial Community Associated with a Wood-Feeding Beetle. $656 \quad$ PLoS One 8:e73827. DOI: 10.1371/journal.pone.0073827.

657 Seigle-Murandi F., Guiraud P., Croizé J., Falsen E., Eriksson KL. 1996. Bacteria Are 658 Omnipresent on Phanerochaete chrysosporium Burdsall. Applied and Environmental 659 Microbiology 62:2477-2481.

660 Seipke RF., Org Barke J., Heavens D., Yu DW., Hutchings MI. 2013. Analysis of the bacterial 661 communities associated with two ant-plant symbioses. Microbiology Open 2:276-283. 662 DOI: $10.1002 / \mathrm{mbo3} .73$.

663 Seniuk OF., Gorovoj LF., Beketova G V., Savichuk HO., Rytik PG., Kucherov II., Prilutskay 664 AB., Prilutsky AI. 2011. Anti-infective properties of the melanin-glucan complex obtained 665 from medicinal tinder bracket mushroom, Fomes fomentarius (L.: Fr.) Fr. 666 (Aphyllophoromycetideae). International Journal of Medicinal Mushrooms 13:7-18. 667 Shen W., Mao H., Huang Q., Dong J. 2015. Benzenediol lactones: a class of fungal metabolites 668 with diverse structural features and biological activities. European Journal of Medicinal 669 Chemistry 97:747-777. DOI: 10.1016/j.ejmech.2014.11.067.

670 Simmonds MSJ. 2003. Flavonoid-insect interactions: recent advances in our knowledge.

671 Phytochemistry 64:21-30. DOI: 10.1016/S0031-9422(03)00293-0. 
672 Smith DJ., Park J., Tiedje JM., Mohn WW. 2007. A Large Gene Cluster in Burkholderia

673 xenovorans Encoding Abietane Diterpenoid Catabolism. Journal of Bacteriology 189:6195-

674 6204. DOI: $10.1128 /$ JB.00179-07.

675 Sobczyk K. 2010. Naturalne inhibitory proteaz asparaginianowych z grzybów rozkładających

676 drewno. D. Phil. Thesis. Maria Curie-Skłodowska University.

677 Speight MCD. 1989. Saproxylic invertebrates and their conservation. Strasbourg: Council of $678 \quad$ Europe.

679 Terra WR., Ferreira C. 1994. Insect digestive enzymes: properties, compartmentalization and 680 function. Comparative Biochemistry and Physiology Part B: Comparative Biochemistry $681 \quad 109: 1-62$.

682 Treutter D. 2005. Significance of Flavonoids in Plant Resistance and Enhancement of Their 683 Biosynthesis. Plant Biology 7:581-591. DOI: 10.1055/s-2005-873009.

684 Vázquez-Baeza Y., Pirrung M., Gonzalez A., Knight R. 2013. EMPeror: a tool for visualizing 685 high-throughput microbial community data. Gigascience 26:2-16.

686 Wagner GK. 2018. Chrząszcze mycetofilne zasiedlające wybrane gatunki hub na terenie 687 południowo-wschodniej Polski. D. Phil. Thesis. Maria Curie Sklodowska University. 688 Warnes GR., Bolker B., Bonebakker L., Gentleman R., Huber W., Liaw A., Lumley T., 689 Maechler M., Magnusson A., Moeller S., Schwartz M., Venables B. 2019. gplots: Various 690 R Programming Tools for Plotting Data. R package version 3.0.1.1. https://CRAN.R$691 \quad$ project.org/package $=$ gplots.

692 Wiater A., Pleszczyńska M., Pietrykowska-Tudruj E., Janczarek M., Staniec B., Szczodrak J. 693 2018. Isolation and characterization of $\alpha-(1 \rightarrow 3)$-glucan-degrading bacteria from the gut of 694 Diaperis boleti feeding on Laetiporus sulphureus. Entomological Science. DOI: 
695

696

697

698

699

700

701

702

703

704

705

706

707

708

709

710

711

712

10.1111/ens. 12332 .

Yang S., Wen X., Shi Y., Liebner S., Jin H., Perfumo A. 2016. Hydrocarbon degraders establish at the costs of microbial richness, abundance and keystone taxa after crude oil contamination in permafrost environments. Scientific Reports 6:37473. DOI: $10.1038 / \operatorname{srep} 37473$.

Yun J-H., Roh SW., Whon TW., Jung M-J., Kim M-S., Park D-S., Yoon C., Nam Y-D., Kim YJ., Choi J-H., Kim J-Y., Shin N-R., Kim S-H., Lee W-J., Bae J-W. 2014. Insect gut bacterial diversity determined by environmental habitat, diet, developmental stage, and phylogeny of host. Applied and Environmental Microbiology 80:5254-64. DOI: 10.1128/AEM.01226-14.

Zhao J-Y., Ding J-H., Li Z-H., Dong Z-J., Feng T., Zhang H-B., Liu J-K. 2013. Three new phenyl-ethanediols from the fruiting bodies of the mushroom Fomes fomentarius. Journal

06 of Asian Natural Products Research 15:310-314. DOI: 10.1080/10286020.2013.764519.

Zhou ZY., Liu JK. 2010. Pigments of Fungi (Macromycetes). Natural Product Reports 27:15311570. DOI: $10.1039 / \mathrm{c} 004593 \mathrm{~d}$.

Zhu F., Du B., Bian Z., Xu B. 2015. Beta-glucans from edible and medicinal mushrooms: Characteristics, physicochemical and biological activities. Journal of Food Composition and Analysis 41:165-173. DOI: 10.1016/J.JFCA.2015.01.019. 


\section{Table and Figure legends}

714 Table 1. Summary of the sequencing data and statistical analysis of microbial communities.

715 Table 2. The level of inhibition, expressed in \% inhibition of the marker enzyme, by protease

716 inhibitors contained in Fomes fometarius fruiting bodies preparations.

717 Table 3. Rf of secondary metabolites spots contained in methanolic and aqueous preparations of

718 fruiting bodies of Fomes fometarius. TLC made in the ethanol-water system. Visualization under

719 a UV lamp at wave lengths of 254 and $365 \mathrm{~nm}$.

720

721 Figure 1. Bolitophagus reticulatus individuals and Fomes fomentarius fruiting body with

722 pictures of sampling sites where they were collected. A - adult and larva of Bolitophagus

723 reticulatus L.; B - fruiting body of Fomes fomentarius (L.) Fr.; C - swampy birch forest, Poleski

724 National Park; D - Carpathian beech forest, Roztocze National Park (phot. G. K. Wagner).

725 Figure 2. Rarefaction analysis and Principal Coordinate Analysis (PCoA) plot of the tested

726 samples. A - Rarefaction curves with Chaol diversity indices, indicating insect microbiome

727 sampling depth and saturation. B - PCoA of bacterial communities associated in tested

728 specimens based on weighted UniFrac distances. The dotted line indicates the sample clustering

729 according to the developmental stage.

730 Figure 3. The heatmap showing bacterial families distributed across B. reticulatus samples. Only

731 those families which relative abundance was not less than $3 \%$ of at least one sample were

732 considered. Cell values were calculated proportionately across rows and dendrograms were

733 estimated with Bray-Curtis dissimilarity index.

734

735 Supplemental Table S1. Number of F. fomentarius fruiting bodies growing on birch and beech

736 trunks and being healthy or inhabited by mycetophagous beetles. 
737 Supplemental Table S2. Detailed taxonomic analyses at different ranks with the data obtained

738 for the developmental stages tested. The table shows the relative abundance of microbial $16 \mathrm{~S}$

739 rDNA sequences for each stage, at different taxonomic levels.

740 Supplemental Data S1. Detailed taxonomic analyses at different ranks for DNA. Sunburst

741 charts show the relative abundance of microbial 16S rDNA sequences at different taxonomic

742 levels. The first level represents the kingdom, the second level represents all phyla present in a

743 particular sample; subsequent next levels represent the class, order, family and genus.

744 Supplemental Figure S1. Predicted functions of bacterial communities associated with tested

745 developmental stages of B. reticulatus. All of the predicted KEGG metabolic pathways are

746 shown at the second hierarchical level and grouped by major functional categories. 


\section{Figure 1}

Bolitophagus reticulatus individuals and Fomes fomentarius fruiting body with pictures of sampling sites where they were collected.

A - adult and larva of Bolitophagus reticulatus L.; B - fruiting body of Fomes fomentarius (L.)

Fr.; C - swampy birch forest, Poleski National Park; D - Carpathian beech forest, Roztocze National Park (phot. G. K. Wagner).
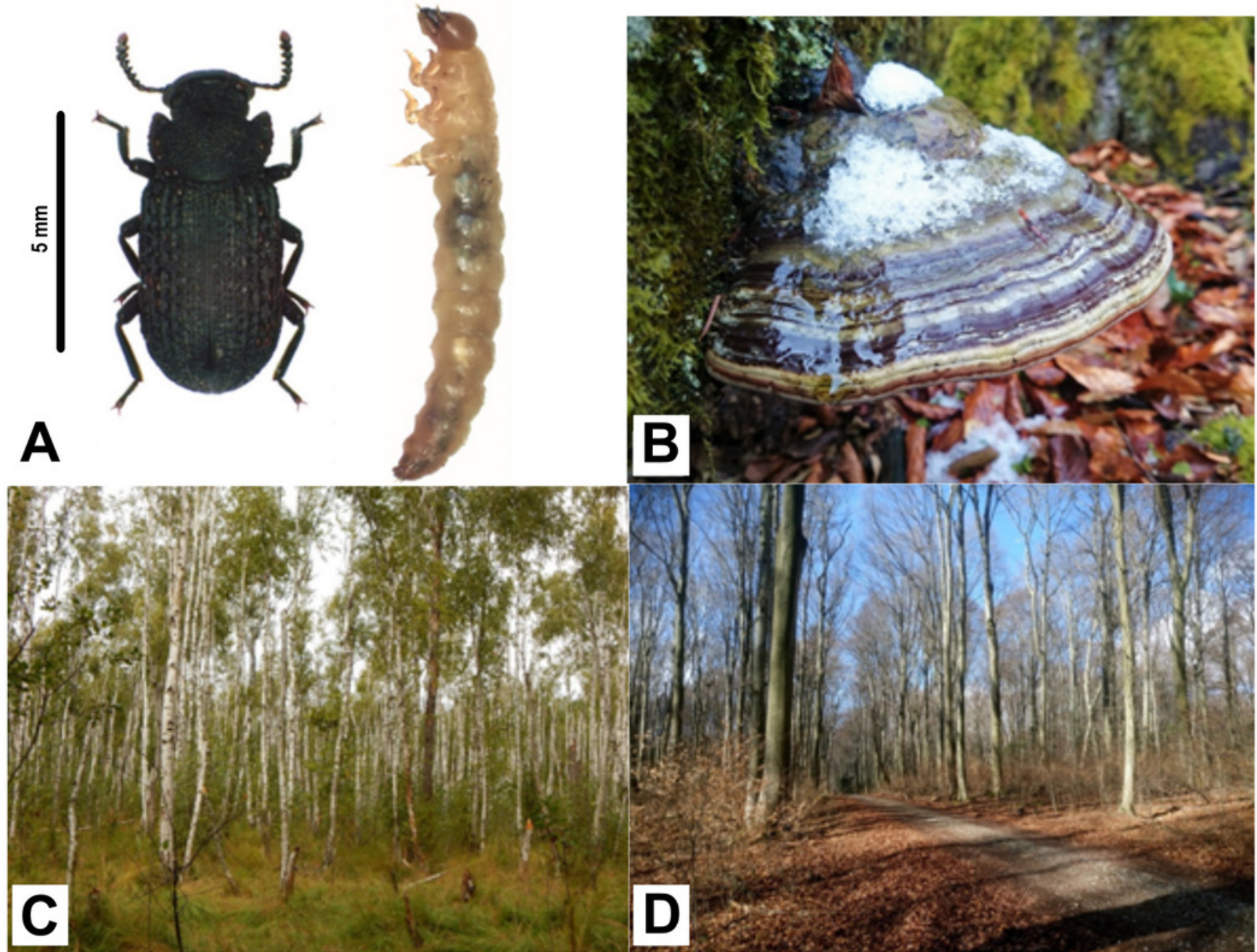
Figure 2

Rarefaction analysis and Principal Coordinate Analysis (PCOA) plot of the tested samples.

A - Rarefaction curves with Chaol diversity indices, indicating insect microbiome sampling depth and saturation. B - PCoA of bacterial communities associated in tested specimens based on weighted UniFrac distances. The dotted line indicates the sample clustering according to the developmental stage.
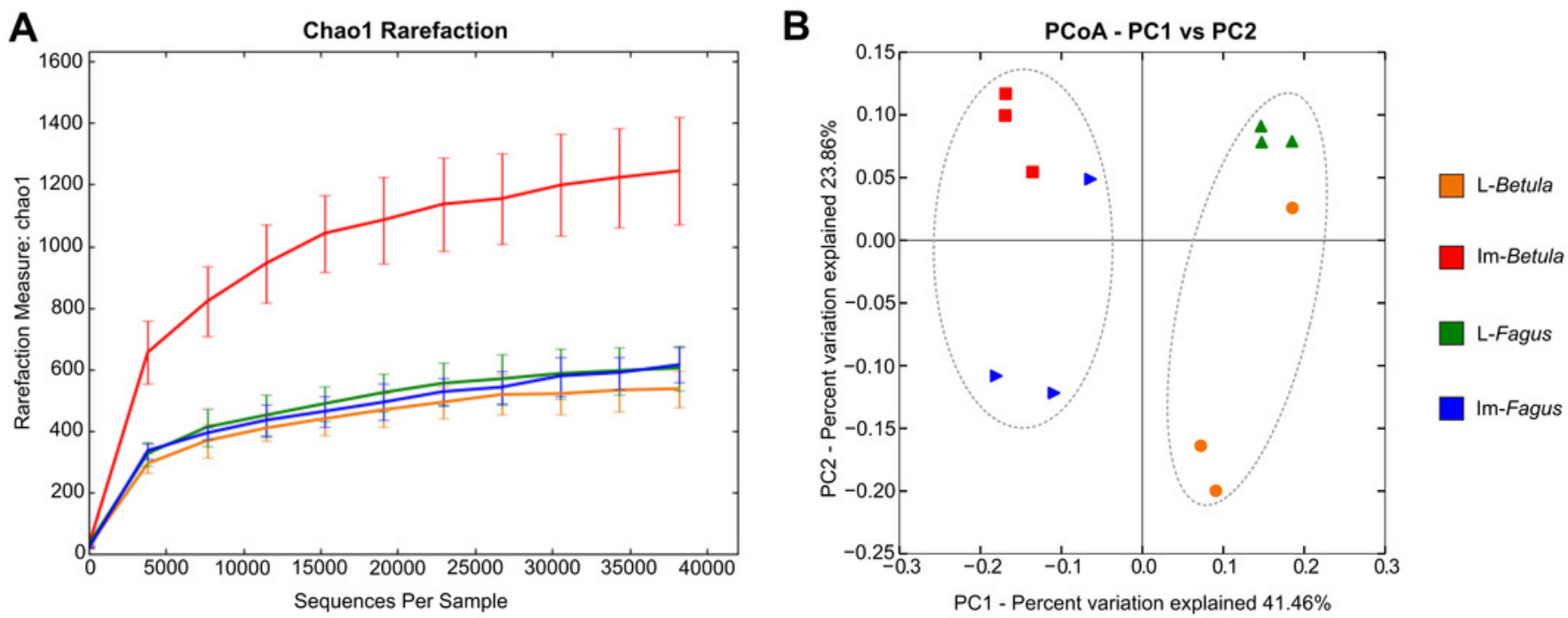
Figure 3

The heatmap showing bacterial families distributed across B. reticulatus samples.

Only those families which relative abundance was not less than $3 \%$ of at least one sample were considered. Cell values were calculated proportionately across rows and dendrograms were estimated with Bray-Curtis dissimilarity index.

Proportion of Reads

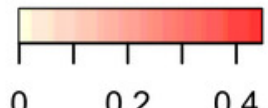

$\begin{array}{lll}0 & 0.2 & 0.4\end{array}$

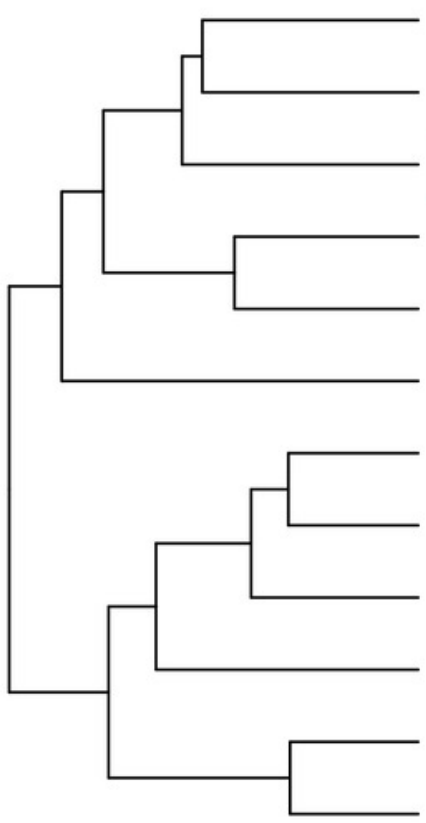

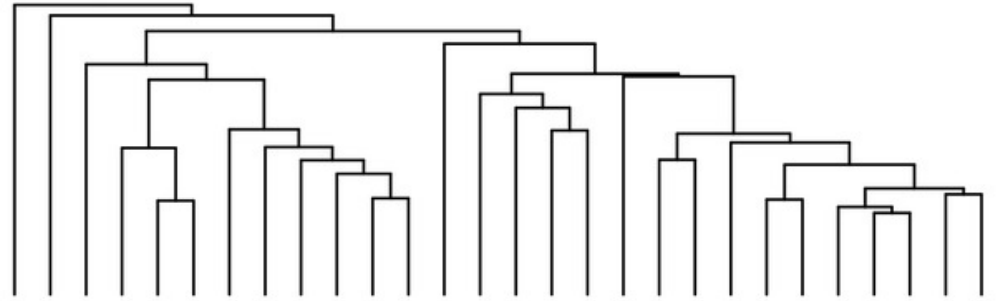

L-Fagus-3

L-Fagus-2

L-Betula-3

L-Betula-2

L-Betula-1

L-Fagus-1

Im-Betula-3

Im-Betula-1

Im-Betula-2

Im-Fagus-3

Im-Fagus-2

Im-Fagus-1

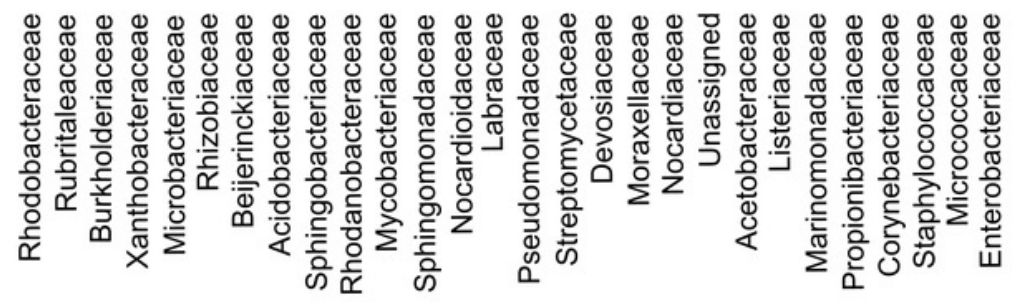




\section{Table $\mathbf{1}$ (on next page)}

Summary of the sequencing data and statistical analysis of microbial communities. 
1 Table 1. Summary of the sequencing data and statistical analysis of bacterial communities

\begin{tabular}{ccccccc}
\hline ID & $\begin{array}{c}\text { No. of } \\
\text { bacterial } \\
\text { reads }\end{array}$ & $\begin{array}{c}\text { Average } \\
\text { length } \\
\text { (bp) }\end{array}$ & $\begin{array}{c}\text { No. of } \\
\text { observed } \\
\text { OTU's }\end{array}$ & $\begin{array}{c}\text { Chao1 } \\
\text { index }\end{array}$ & $\begin{array}{c}\text { Shannon } \\
\text { index }\end{array}$ & $\begin{array}{c}\text { Simpson } \\
\text { index }\end{array}$ \\
\hline L-Betula-1 & 53,423 & 454 & 463 & 552 & 5.86 & 0.95 \\
L-Betula-2 & 38,188 & 451 & 319 & 453 & 5.30 & 0.94 \\
L-Betula-3 & 71,060 & 450 & 527 & 594 & 6.04 & 0.96 \\
Im-Betula-1 & 71,537 & 452 & 918 & 1017 & 5.96 & 0.95 \\
Im-Betula-2 & 59,894 & 452 & 1195 & 1395 & 6.96 & 0.98 \\
Im-Betula-3 & 73,856 & 452 & 1223 & 1236 & 6.72 & 0.97 \\
L-Fagus-1 & 70,693 & 450 & 486 & 641 & 6.01 & 0.94 \\
L-Fagus-2 & 47,193 & 449 & 433 & 573 & 6.39 & 0.98 \\
L-Fagus-3 & 48,758 & 450 & 576 & 725 & 6.16 & 0.96 \\
Im-Fagus-1 & 49,161 & 454 & 432 & 524 & 4.90 & 0.90 \\
Im-Fagus-2 & 51,603 & 454 & 485 & 554 & 5.20 & 0.92 \\
Im-Fagus-3 & 62,315 & 450 & 571 & 624 & 5.59 & 0.94 \\
Total & 697,681 & 451 & 2527 & 741 & 5.92 & 0.95 \\
\hline
\end{tabular}

2 The ID abbreviations are defined in text. The number of OTUs (operational taxonomic units) was

3 generated at the $97 \%$ sequence similarity cut-off. Diversity indices represent the randomly selected 4 subsets for each sample normalized to 38,188 sequences. 


\section{Table 2 (on next page)}

The level of inhibition, expressed in \% inhibition of the marker enzyme, by protease inhibitors contained in Fomes fometarius fruiting bodies preparations. 
1 Table 2. The level of inhibition, expressed in \% inhibition of the marker enzyme, by protease

2 inhibitors contained in Fomes fometarius fruiting bodies preparations.

3

\begin{tabular}{cccccc}
$\mathbf{p H}$ & $\begin{array}{c}\text { Marker } \\
\text { enzyme }\end{array}$ & $\begin{array}{c}\text { Fagus sp. } \\
\text { Healthy } \\
\text { fungus }\end{array}$ & $\begin{array}{c}\text { Inhabited } \\
\text { fungus }\end{array}$ & $\begin{array}{c}\text { Betula sp. } \\
\text { fungus }\end{array}$ & $\begin{array}{c}\text { Inhabited } \\
\text { fungus }\end{array}$ \\
\hline 5.0 & pepsin & $6.20 \pm 0.03$ & 0.3 & $3.40 \pm 0.02$ & $0.10 \pm 0.01$ \\
7.0 & papain & $0.20 \pm 0.01$ & 0 & $9.80 \pm 0.03$ & $5.70 \pm 0.03$ \\
& trypsin & 0 & 0 & $2.50 \pm 0.02$ & $0.20 \pm 0.01$ \\
9.0 & trypsin & $0.10 \pm 0.01$ & 0 & $0.10 \pm 0.01$ & 0 \\
\hline
\end{tabular}

4

5 


\section{Table 3 (on next page)}

Rf of secondary metabolites spots contained in methanolic and aqueous preparations of fruiting bodies of Fomes fometarius.

TLC made in the ethanol-water system. Visualization under a UV lamp at wave lengths of 254 and $365 \mathrm{~nm}$. 
1 Table 3. Retardation factor (Rf) of secondary metabolites spots contained in methanolic and 2 aqueous preparations of fruiting bodies of Fomes fometarius. TLC plates were developed using 3 the ethanol-water system and were visualized under a UV lamp at wavelengths of 254 and 365 $4 \mathrm{~nm}$.

\begin{tabular}{|c|c|c|c|c|c|c|}
\hline \multirow{2}{*}{ Extract } & \multirow{2}{*}{$\begin{array}{c}\text { UV } \\
\text { wavelength } \\
\text { (nm) }\end{array}$} & \multicolumn{2}{|c|}{ Fagus sp. } & \multicolumn{2}{|c|}{ Betula sp. } & \\
\hline & & $\begin{array}{c}\text { Healthy } \\
\text { fungus }\end{array}$ & $\begin{array}{c}\text { Inhabited } \\
\text { fungus }\end{array}$ & $\begin{array}{c}\text { Healthy } \\
\text { fungus }\end{array}$ & $\begin{array}{c}\text { Inhabited } \\
\text { fungus }\end{array}$ & \\
\hline \multirow{3}{*}{ Methanol } & 365 & $0.8235+$ & $0.8235+$ & $0.8235+$ & $0.8235+$ & \\
\hline & 254 & $0.7058++$ & $0.7058+$ & $0.7058+$ & $0.7058+$ & $* *$ \\
\hline & 254 & $\begin{array}{c}0.1176 \\
+++\end{array}$ & - & - & - & \\
\hline \multirow{3}{*}{ Water } & 365 & $0.9092+$ & - & - & - & \\
\hline & 254 & $0.7882++$ & - & - & - & $*$ \\
\hline & 254 & $0.7058+$ & $0.7058+$ & $0.7058+$ & $0.7058+$ & $* *$ \\
\hline
\end{tabular}

5

$6+,++,+++$ - intensity of UV spots,

$7 \quad *$ - catechins and their derivatives,

$8 \quad * *$ - sesquiterpenes lactones. 